\title{
ADAPTATION: THE KEY TO THE PROBLEM IN SHOCK? ${ }^{\circ}$
}

\section{S. G. HeRShEY, M.D. AND B. W. ZweIFACH, PH.D.革}

A COMPREHENSIVE DESCRIPTION of the pathogenesis of shock is not, as yet, available. In fact shock cannot be defined validly to include all the clinical and experimental circumstances which lead to the development of this syndrome. This situation more than any other, perhaps, probably underlies the absence of the normal transfer of significant laboratory findings to clinical use. For by most standards, the management of shock in patients has seen little recent progress and remains virtually empiric. In a sense, this is the major problem in shock. Yet much is known about this entity on an experimental basis. The accumulation of so much data over so many years, by so many investigators should reasonably be expected to have provided some, if not all, of the critical answers sought. A reappraisal of the information already available, therefore, seems very much in order. If nothing else, such a "new look" may direct attention to areas for profitable exploration.

One cannot but conclude that shock, whatever else it may be, is a circulatory disturbance-primarily a peripheral vascular decompensation. Failure of the microcirculation in tissues develops in all forms of shock and basically defines the syndrome in limited, but generally acceptable terms. There is no question but that this pattern of vascular collapse can be generated by any number of familiar circumstances, well-described mechanisms and specific toxic substances, the investigation of which has resulted in the many theories and concepts offered by various investigators over the years. But it is not known whether this vascular collapse is primarily the consequence of imposing any of a broad array of these noxious factors on an already predisposed host; or whether the vascular collapse is primarily due to the fact that the host, in some way as yet unknown, is rendered susceptible to these factors by impairment of his homeostatic defence mechanisms. This uncertainty as to whether any factor which has been implicated in shock is therefore either ancillary, or related to the more basic disturbance in homeostatic defence mechanisms, more than likely explains why so many concepts and theories of the pathogenesis of shock, however impressively and intriguingly developed, have not held up. $\$$

'Some of the authors' investigations reported here were supported in part by grants from the USPHS (H-5409, H-2267) and the Levy Foundation for Medical Research, New York City.

Presented at the Sixteenth Annual Meeting of the Canadian Anaesthetists' Society, Western Division, March 8-11, 1961, Winnipeg, Manitoba.

†From the Departments of Anesthesiology and Pathology, New York 'University Medical Center and Beth Israel Hospital, New York, N.Y.

\$Below are listed some of the investigators whose names are associated with various "major" concepts of the pathogenesis of shock. It is immediately apparent that the study of the shock syndrome has attracted the serious attention of many of the most prominent and respected investigators during this century. The fact that a valid, unified concept of shock has not been

Can. Anaes. Soc. J., vol, 8, no. 6, November, $19 \dot{6} 1$ 
It has been shown in many ways that the normal subject whose defence mechanisms are unimpaired, will safely tolerate circumstances which are lethal to the shocked individual. Conversely it has also been demonstrated that spontaneous or deliberate impairment of intrinsic defence mechanisms will convert a sub-lethal shock stimulus to one which is lethal. ${ }^{1}$ But more significant emphasis on the basic role of homeostatic mechanisms in the body's adjustment to stress are the data indicating that any injury which is highly lethal to the normal individual is readily tolerated by the subject who has been previously conditioned by deliberately accelerating the level of activity of his defence mechanisms. ${ }^{2-4}$ In fact stimulation of these inherent mechanisms by noxious factors seems to be the normal physiologic pathway whereby the body readjusts its routine responses in order to cope with many unfavourable stimuli to which it is exposed by its environment. 5 The biological processes by which this is aecomplished are collectively termed adaptive phenomena. It is to these processes that attention is directed here in so far as these relate to the course of events in shock. This is of extreme interest not only as a significant theoretical consideration but also because it has obviously important clinical implications.

It is generally recognized that individuals -differ widely in their capacity to tolerate stressful situations. Such differences are usually ascribed to factors of age, sex, nutrition, genetic background, physical status, etc. While these prosaic factors are of unquestionable importance, clinicians have always also recognized the existence of more subtle factors as being significant, even though they are less readily labelled. Ordinarily the consideration of these factors is focused on the unfavourable influence they exert on the defence potential. But if this potential could be deliberately manipulated in the opposite, favourable direction, the appreciation of the elements involved in this favourable shift could be of extreme value. The identification of these elements might afford the resources to convert a "weakling" to normal or a normal individual to a "superman" who is appropriately defined by Nietzsche as the goal of the evolutionary struggle for survival. This is far from a new thought and probably has its origins in antiquity, dating from before the time of the Roman gladiators through the present-day highly conditioned boxers and football players. The remarkable thing about athletes in contact sports is their capacity to withstand physical violence which would seriously injure most normal men of otherwise comparable structural attributes.

derived from the work of men of such outstanding scientific stature bears eloquent testimony to the elusiveness of the fundamental solution of the problem.

1899: Crile--Vasomotor exhaustion.

1903: Howell-Cardiac plus vascular etiology.

1908: Henderson-Venomotor atonia $\left(\mathrm{CO}_{2}\right)$.

1908: Meltzer-Central reflex inhibition.

1916: Porter-Fat embolism.

1918: Dale and Richards-Histamine, capill. perm., toxic

1919: Erlanger and Gasser-Splanchnic pooling, epinephrine

1919: Gesell-Tissue ischemia

1921: Mcleod-Acidosis

1923: Cannon-Vasotoxic dilation, humoral factors
1923; Wiggers-Cardiac insuff., " $H$ " subs., physical vasc. imbal.

1933:| Freeman-Neurogenic factors, epinephrine

1936: Swingle-Adrenal cortex

1937: Blalock-Regional sequestration, blood vol. deficit

1938: Scudder-Hyperpotassemia

1942: Moon-Capillary damage

1944: Aub-Clostridia, exotoxins

1944: Hastings-Kallikrein

1950: Shorr-Ferritin

1955: Fine-Bacterial endotoxins 
They do not so readily sustain tissue injury and when injured heal at an accelerated pace.

In the laboratory, the deliberate induction of resistance to physical injury can probably be first attributed to Noble's findings ${ }^{2}$ less than twenty years ago. By subjecting rats and guinea-pigs to repeated, sub-lethal episodes of tumbling trauma in a rotating drum, he developed groups of animals almost all of which readily survived degrees of injury highly fatal to their untrained controls. Interestingly these animals were popularly called Commandos, as the laboratory counterpart of their human relatives then being trained for more grim purpose. Ever since then many investigators have been trying to learn why the Commando or resistant animal is resistant. To those interested in the study of shock it was obvious that the experimental interplay of such resistance-inducing or protective factors in the response to a shock stimulus could provide a valuable research tool. And, in fact, much of the information recently developed about shock has come from such protection studies.

Protection against various forms of experimental shock can be induced in many ways. Characteristically, this type of adaptation is initiated by subjecting laboratory animals to "training programmes" consisting of exposure to sub-lethal noxious stimuli or to various drugs prior to the challenge of a highly lethal shock stimulus. The techniques (Table I) used are reliable, reproducible and so diverse as to

TABLE I

Typical Methods of Protection against Experimental Shock"

Tumbling (drum) trauma

Antibiotics (many)

Autonomic blocking agents (many)

Bacterial endotoxins

Amine depletion (48/80)

RES stimulation (inert colloids)

Epinephrine tolerance

Cold

"Haemorrhage, trauma, endotoxemia, tissue ligation. Rat, dog, guinea-pig, mouse, rabbit.

have seemingly little relationship to each other in terms of common physiologic or pharmacodynamic denominators. In typical experiments the shock stimuli (haemorrhage, trauma, tissue ligation or toxic compounds) are not altered of themselves when applied to the resistant or adapted animal. The latter's survival must reside, therefore, in the assumption that the usual reaction to the shock stimulus has been altered in some way by the pre-shock preparatory procedure. In fact many specific differences between the reactions of normal and resistant animals to stress have been determined in relation to the individual techniques utilized to induce resistance and to produce shock. These differences cover many parameters which have been measured and include such varied features as: the rate and extent of compensatory haemodilution ${ }^{6}$; maintenance of more stable and favourable blood pressure levels ${ }^{3}$; prompt and sustained response to transfusion ${ }^{3}$; minimal splanchnic sequestration of blood ${ }^{7}$; persistence of aerobic metabolism in hypoxic tissues ${ }^{8}$; sustained production of vasoexcitatory polypeptides ${ }^{9}$; in- 
creased elaboration of vasotropic amines. ${ }^{10}$ Collectively, these differences between control and resistant animals imply that the latter, during stress, develop and maintain a broad spectrum of homeostatic responses which are recognized as, or presumed to be, compensatory in nature. In other words, the protective procedure can be considered to have stimulated or adapted the animal's normal defence potential to a higher level of competency.

Admittedly, defence potential, per se, is a rather vague term. Perhaps it can be somewhat better delineated if defence mechanisms are related to the pathways by which protective procedures may operate. Analysis of the available data on protection, when oriented towards revealing such pathways, can be approached in two ways: by examining cross tolerance to different types of shock as induced by individual protective procedures; and by relating known or potential characteristics of individual protective procedures to factors which have beenerimplicated as critical in the shock response. A full and detailed review of the extensive data bearing on experimental protection is not feasible at this time. But the present objective of a "new look" can be developed from a synthesis"11,12 of this data and a few illustrative details.

It is well established (Table II) that cross-tolerance to shock does exist. ${ }^{13}$ If the incidence and extent of such cross tolerance is examined it becomes apparent that the pathways by which the separate protective procedures operate, while

TABLE II

Cross Tolerance following Various Adaptive Regimes*

\begin{tabular}{lcccc}
\hline & \multicolumn{4}{c}{ Type of Experimental Shock } \\
\cline { 2 - 5 } Adaptive Regime & $\begin{array}{c}\text { Drum } \\
\text { trauma }\end{array}$ & Haemorrhage & $\begin{array}{c}\text { Endotoxin } \\
\text { tolerance }\end{array}$ & $\begin{array}{c}\text { Bowel } \\
\text { ischemia }\end{array}$ \\
\hline Drum training & ++ & + & \pm & + \\
Aureomycin & + & ++ & 0 & + \\
Endotoxin tolerance & ++ & ++ & ++ & + \\
RES stimulation & ++ & ++ & + & unkn. \\
Amine depletion & ++ & ++ & + & + \\
Dibenzyline & ++ & + & \pm & unkn. \\
Cold $\left(0^{\circ} \mathrm{C}-3\right.$ days & ++ & ++ & \pm & unkn. \\
Epinephrine tolerance & ++ & + & + & +
\end{tabular}

*This tabluation of cross tolerance is based on data reported by various authors for the rat, rabbit or dog. No inferences are intended for adaptive procedures or types of experimental shock not listed.

$+=$ tolerance, $0=$ no tolerance, $\pm=$ inconsistent tolerance, unkn. $=$ unknown.

they are not entirely identical, seemingly have many features in 'common. Or these pathways, in regard to the defence mechanisms they accelerate, must effectively cross react. Stated otherwise, while no completely common denominator to all modalities of protection against various types of shock is revealed, there is an impressive degree of "commonness" suggested as regards the mechanisms of defence although it is not possible to identify these mechanisms.

When one probes beyond this generalization regarding the mechanisms involved in the adjustment to stress and carefully threads a path through the maze 
of relevant data, several interesting features seem to separate themselves out. On the one hand, mechanisms biologically housed in the intestine and liver are revealed as important constituents of the body's defences. There is extensive and convincing evidence ${ }^{10,14}$ that the intestine responds to shock by elaborating or releasing materials with marked vasotropic effects. Comparable ${ }^{10,15}$ evidence indicates that the liver responds by mediating or "decontaminating" such materials from the intestine or from other sites. On the other hand, and this is more pertinent to the purpose of the present discussion, in relation to the diverse factors which have been implicated in the shock reaction, these crystallize themselves by pointing to a close correlation between the character of the resistance which develops and the behaviour of the normally present tissue mediators such as the catechols, histamine, serotonin and vasotropic polypeptides. For example, ferritin ${ }^{16}$ and bacterial endotoxin ${ }^{17}$ probably represent the most elaborately documented factors which have been postulated as critical participants in the vascular failure leading to irreversibility. The disruptive cycle generated by both of these totally unrelated discrete substances ultimately leads to their comparable effects on these humoral tissue mediators. Ferritin in its toxic reduced form triggers the oxidation of adrenaline to adrenochrome. ${ }^{18}$ Endotoxin response is characterized by a tremendously exaggerated response of small blood vessels to vasoactive amines. ${ }^{19}$ A similar relationship to these tissue mediators exists for such other shock factors as increased proteolytic activity, adrenal exhaustion, antibody depletion, impaired capillary integrity ( $\mathrm{H}$-substances), neurohumoral imbalance, etc. The special significance of the involvement of these vasoactive tissue agents in the chain of events in shock lies in their emphasis on the intimate relationship between the functional behaviour of the small blood vessels and the metabolic activity of the tissues in closest proximity to these vessels.

For if shock is a syndrome of peripheral vascular failure, it is also an expression of impaired tissue function mediated by this microcirculatory failure. The remarkable feature of both of these manifestations of shock is their unexplained predilection to interreact and become a self-perpetuating vicious cycle progressively impervious to corrective therapy. The autonomy of this interdependent tissue-vascular complex probably poses the basic problem in shock. This selfdefeating response may, in fact, represent a phylogenetic adaptive reversion to very early animal forms. ${ }^{*}$ In seeking to explore for the factors which govern the quality of the reaction to injury, it therefore seems logical to examine systems which function primarily to monitor and protect the phylogenetically primitive

\footnotetext{
'In the evolution from simple to complex animal species the maintenance of cellular functional integrity could no longer depend on purely local, simple means of exchange between the cells and the environment. The development of the complex circulatory system and its regulatory mechanisms to satisfy such exchange in higher forms, did not bring with it, however, the total replacement of the antecedent local regulation which still retained considerable of its actual and potential functional capacity. During severe stress in which the newer "central" circulatory mechanism becomes progressively incapable of providing access to needed metabolic interchange, the deprived tissues react by "seceding," in a sense, from the inefficient central system and revert to the primitive local regulatory mechanisms in an attempt to increase their metabolic resources. If this ascendancy of local regulation is sufficiently widespread, particularly in so-called critical tissues, the result can be likened to a type of biologic anarchy leading to a hopelessly disrupted central circulatory mechanism which, of itself, negates the purposive nature of the reactivated local mechanisms.
} 
homeostatic balance between the microcirculation and the tissues from abnormal and unfavourable circumstances.

With this in mind and without either accepting or rejecting Fine's thesis of the "universality" of bacterial endotoxins as the key substance leading to irreversibility, his emphasis on the mutuality of the normal mechanisms of resistance to shock and normal bacteriological defence mechanisms is provocative. Teleologically, in a general biologic sense, this is quite reasonable since even the earliest living forms have had to live with and protect themselves against bacteria. It becomes even more reasonable if we assume that bacterial defence mechanisms are not the whole but a part of the body's normal battery of defences. There is much data from Fine's laboratory ${ }^{20}$ and from many other sources ${ }^{12}$ concerning the response to shock in normal, predisposed and protected animals which is in surprising harmony with this postulate. At least, examination of the mechanisms involved in the defences against bacteria and bacterial products might possibly lead us closer to the factors governing the character of the adaptation to injury.

The tissue system housing many of the body's defences against bacteria is the reticulo-endothelial system (RES) ${ }^{21} \mathrm{It}$ is a matter of particular interest, therefore, that this same tissue system is found to be a major participant in many of the physiologic changes which occur in experimentally protected animals. ${ }^{11,12}$ Furthermore, the RES is an integral link in the chain of events set in motion by endo. toxemia, ferritinemia, exotoxemia and virtually all of the other factors implicated in various concepts of shock based on experimental data-from micro-thrombi through hypersensitivity, capillary permeability, etc. The RES is phylogenetically primitive, widely distributed anatomically, functionally versatile and adaptive and, as mentioned previously, deals closely with the maintenance of the normal relationship between the microcirculation and the tissues. The role of the RES in the response to stress might profitably be examined in some detail. To do this in proper perspective, however, it might be helpful to review briefly something of what is known of the make-up and function of the RES. ${ }^{21}$

By and large the RES is usually regarded as widely distributed groups of cells which function primarily to trap abnormal and foreign materials from the blood stream by phagocytosis. This viewpoint also includes the assumption that besides mechanically removing such materials from the blood, these cells also possess biochemical mechanisms for breaking down most of these ingested materials to non-toxic, excretable products. As such, these cells form an integral part of the endothelial barrier separating the blood and parenchyma in such organs as the liver, spleen, lymph nodes and bone marrow. They function continuously to cleanse the blood and tissue spaces of cellular debris and foreign materials which they break down and then pass on to appropriate parenchymal organs for excretion. The RES is well suited for this purpose not only because of its strategic distribution, but also because of its intrinsic capacity to hypertrophy structurally and functionally when challenged by materials requiring removal and inactivation. Actually not too much is known of the functions of the RES other than that which deals with its phagocytic behaviour. But recent renewed interest in it is demonstrating the existence of a rapidly growing number of important functions ${ }^{22}$ 
which the RES has in the regulation of a wide variety of homeostatic mechanisms. Some of these additional functions (Table III), to mention only a few, include: regulation of circulating leucocytes, platelets, plasma fibrinogen, various antibodies and blood proteolytic activity. Other RES functions are related to regional

TABLE III

Mechantsms KNOWN to Be INFLUENCED By RES

\begin{tabular}{l}
\hline Antibacterial \\
Leucocyte, platelet and fibrinogen levels \\
Phagocytic clearance of colloids \\
Antibody, Properdin levels \\
Coagulation of blood \\
Blood proteolytic activity \\
Intrahepatic Blood Flow \\
Ferritin inactivation-Iron incorporation \\
Blood volume regulation \\
Reactivity of microcirculation to humoral agents \\
\hline
\end{tabular}

blood flow (particularly in the liver), transfer of iron to its storage sites, regulation of blood volume and the behaviour of small blood vessels by conditioning their responses to vasotropic humoral agents. Many abnormal states such as adrenal insufficiency, severe infection and shock are accompanied by a depressed RES. Conversely other abnormal states are accompanied by a hyperactive RES. The latter circumstance of a stimulated RES is particularly notable because it often follows recovery from disturbances which were initially depressive to the RES. This is particularly true of infections. ${ }^{21}$

Means of assessing the functional state of the RES are limited to visual estimates of its enlargement and cellular characteristics or to measurements of its phagocytic activity. The relative phagocytic efficiency of the hepatic RES can be illustrated (Fig. 1) by injecting inert colloidal carbon into the animal and subsequently ( $15 \mathrm{~min}$. to $1 \mathrm{hr}$. usually) examining the liver microscopically for visual evidence of the amount and distribution of carbon ingested by the Kupffer cells. A somewhat more quantitative estimate of RES phagocytic activity can be determined by the rate at which particulate matter and macromolecules such as carbon, colloidal iron, thorium oxide and radioactive chromium disappear from the blood stream. This measurement yields a clearance curve which can be quantitated ${ }^{23}$ to derive the so-called phagocytic index as a numerical value of total body phagocytic activity (Fig. 2).

Experimentally, the RES can be depressed by injecting sufficient materials such as carbon, thorium oxide or radioactive chromium saturate the system to a level referred to as RES blockade. The system can be mulated by repeated periodic injections of moderate amonnts of the same tyl of substances which are phagocytized. In time, this process produces a state of hypertrophy and hyperplasia.

With this brief description of the RES as a frame of reference, the role of this system in the response to stress can now be considered. RES activity in shock can also be related to circumstances and mechanisms which are commonly 
associated with the syndrome. Unfortunately the information bearing on this is not yet extensively documented. But the recent investigations of the RES in shock reported from several laboratories and the growing knowledge of the RES, per se, reported from many sources can be profitably utilized in exploration of our approach.
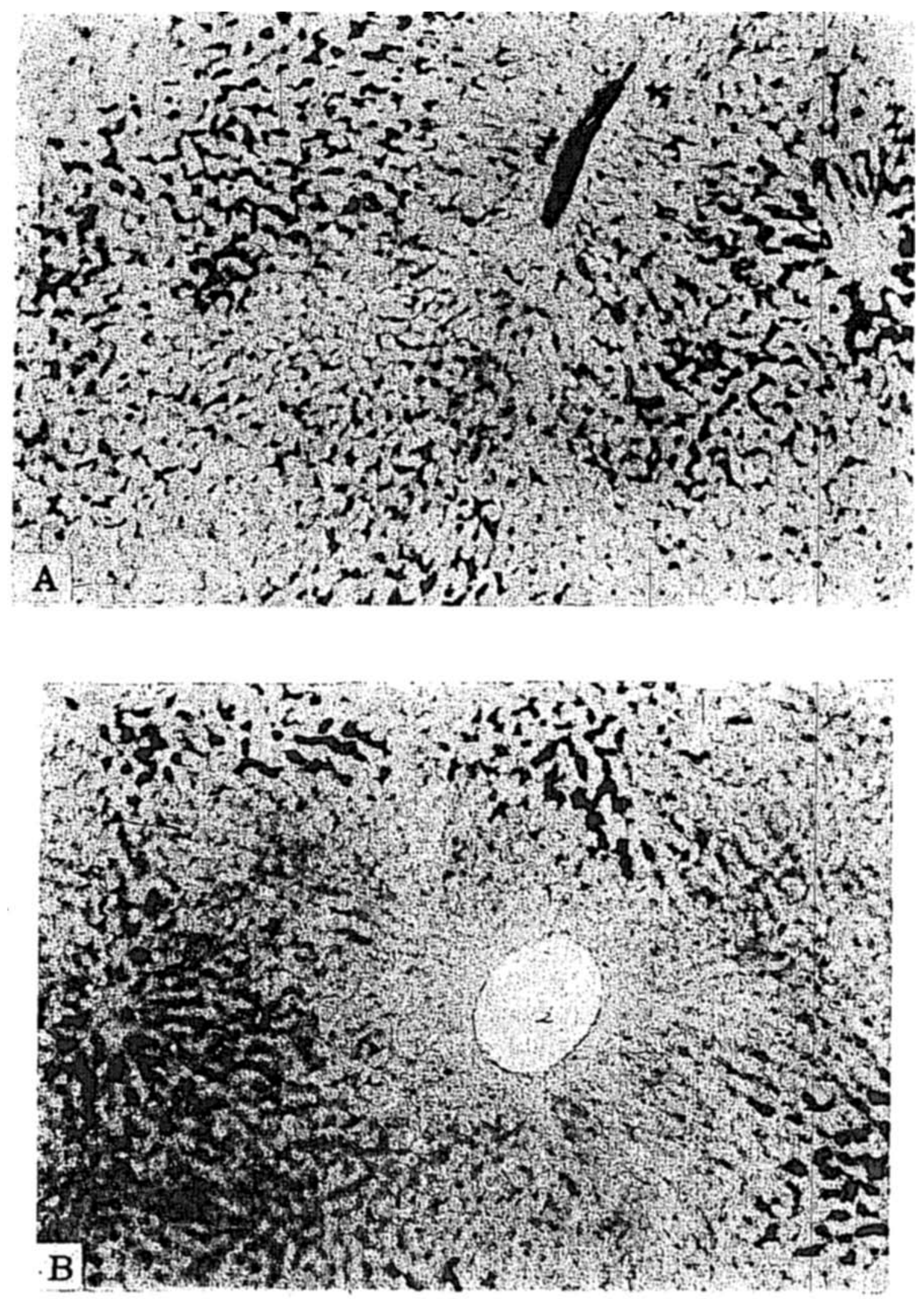

FIGUHE 1. Photomicrographs of carbon distribution in Kupffer (RES) cells of liver of rats. Carbon injected I.V. as colloidal suspension in gelatin (Pellikian), $2.0 \mathrm{mg} / 100 \mathrm{gm}$. body wt. $\mathrm{A}=$ normal rat. Note even distribution of carbon throughout all lobules. $\mathrm{B}=$ Irreversible haemorrhagic shock. Note uneven distribution and absence of carbon about central venules. 


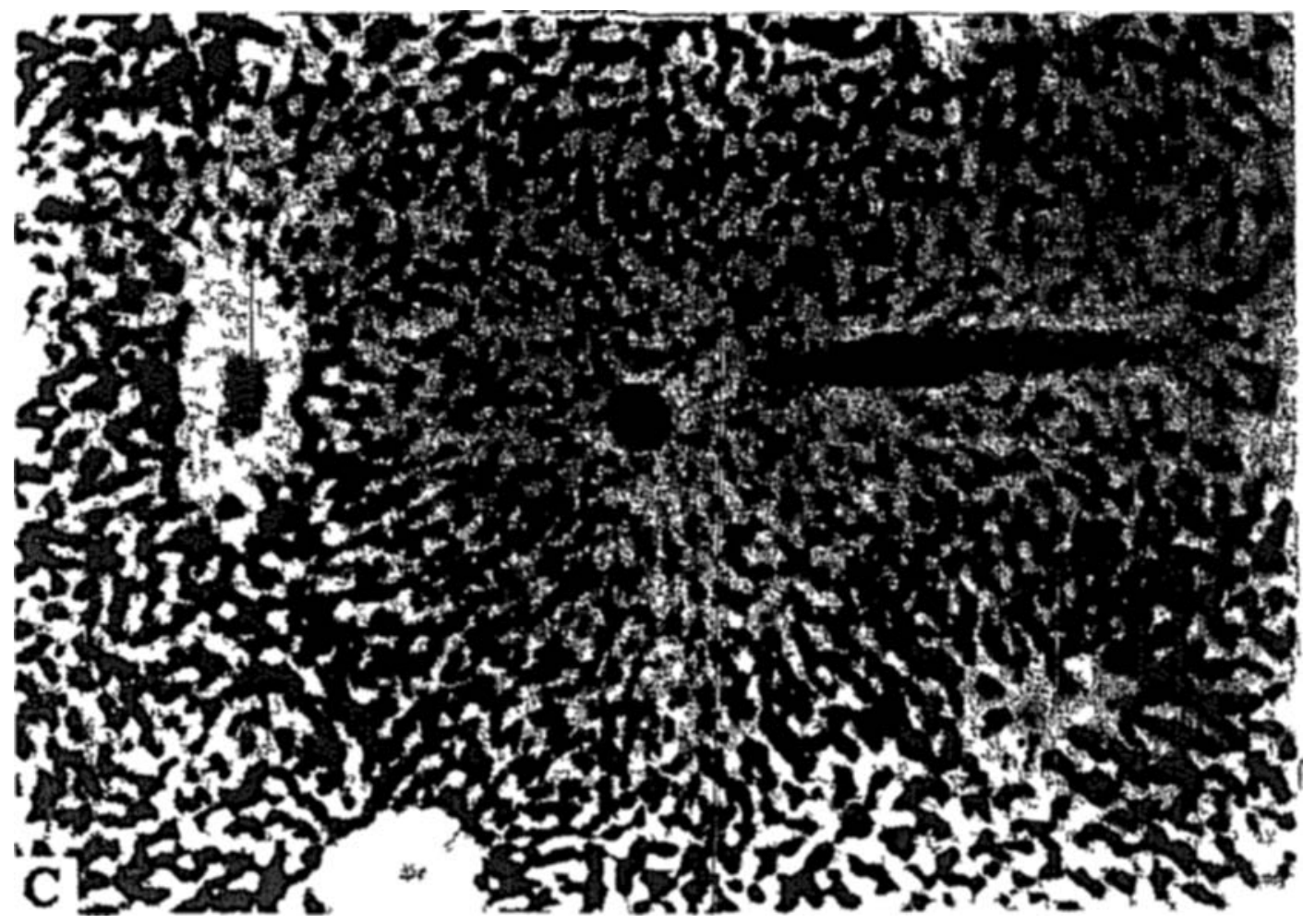

TIGURE 1 (continued) $\mathrm{C}=$ Stimulated RES (zymosan pretreatment- 4 days) Note marked uncrease in carbon in Kupffer cells throughout all lobules Magnification 30x

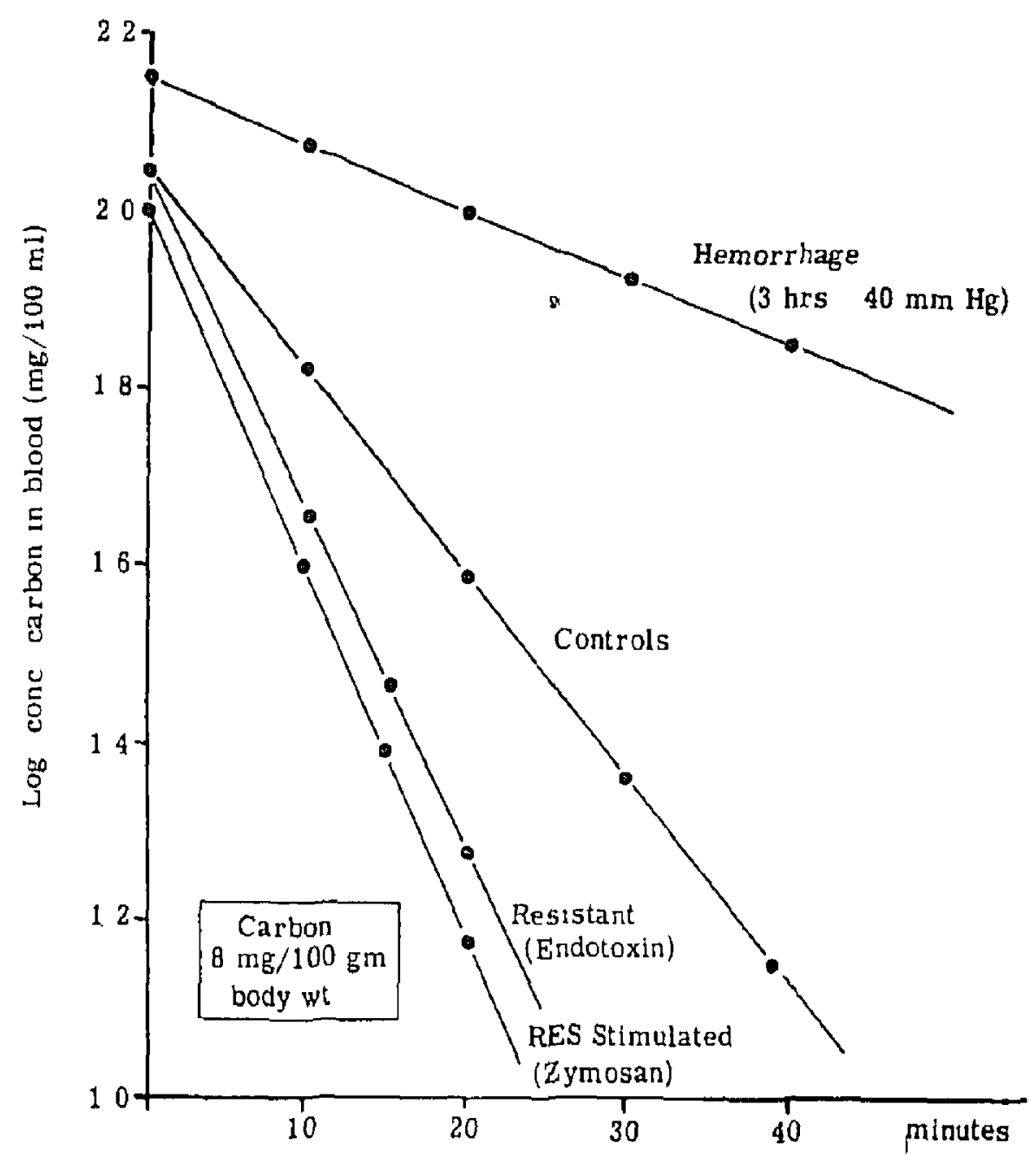

Figure 2 Curbon cle ir unce curves (logarthmu) inf $r$ its with normal depiessed (hiemor thagic shoch) and stum il ited (cndotoun tolernint zymosinn pretrentment) RES Carbon con c ntration detern ned i scrul plasma simples using Colem in colorimeter 
Does interference with the RES actually lead to a reduced capacity to withstand stress? Blockade of the RES with carbon, Proferrin, or Thorotrast ${ }^{24,25}$ was found to decrease considerably the normal animal's tolerance to all forms of experimental shock examined. In fact, this technique has been employed ${ }^{25}$ as a specific, reliable experimental method of predisposing normal animals to shock in investigation of other aspects of the syndrome. Quantitative estimates of RES clearance of injected colloids during the course of shock demonstrated a progressive decline in phagocytic efficiency which reached its lowest value at the time the animals became refractory to therapy. ${ }^{26}$ When the same type of blockade was induced in animals previously made resistant to shock, this resistance was abolished temporarily for periods up to twelve hours. This was true regardless of the modality which had been used to induce the pre-existent protected state. The rapid return of this protected state in conjunction with the disappeance of the blockade points to another important relationship between a functionally already stimulated RES and the ability to tolerate stress. It is common experience in the laboratory that when a normal dog is bled vigorously and the shed blood is reinfused before the animal is severely hypotensive for too long and is not irreversible, it recovers promptly and appears entirely normal within 24-48 hours. Most of the usual cardiovascular criteria are also within normal limits except for some increase in circulating blood volume due to haemodilution. However if this same dog is subjected to haemorrhagic shock within this 24-48 hour recovery period it is more easily rendered irreversible. When RES clearance is determined in the normal animal which has been bled and successfully transfused, ${ }^{26}$ the marked depression in RES capacity noted during the haemorrhagic episode continues for 48-72 hours into the period of apparent recovery. In this post-shock interval the RES is almost incapable of being stimulated. During this recovery period a single blocking dose of carbon will produce a long, profound and often unrelieved blockade.

In contradistinction to these findings in normal animals, RES clearances which are initially more efficient because of stimulation fall much less and for briefer periods during and following a haemorrhagic shock episode. ${ }^{26}$ The hyperactive state is spontaneously resumed much earlier in the recovery period. Carbon blockade at this time is not as profound or prolonged as in the normal animal Stimulation of the RES not only increases the capacity to withstand haemorrhage but also imparts increased resistance to trauma. This is true irrespective, of the factor used to stimulate the RES and depends solely on the ability of the agent to increase RES clearance capacity.

There is one additional circumstance bearing on the RES which might be mentioned. One of the early observations in shock was that considerable stimulation of adrenal function occurred. At one time the adrenal cortex was believed to occupy the key role in determining the resistance of animals to stress. One need only recall the routine use of DOCA for patients in shock to emphasize the former wide acceptance of this belief. Without any present implication as to the correlation of Selye's concept of adaptation by adrenal mechanisms, the feeling that the adrenal cortex may be significantly involved in the| shock response 
still widely exists. This is witnessed by the frequent inclusion of cortisone in routine anti-shock therapy. As is well recognized, adrenalectomized animals are highly susceptible to shock. It is of interest therefore to ascertain whether there is an association between the adrenal gland and the changes seen in the RES during adaptive procedures.

It was found that repeated doses of ACTH resulted in physical hypertrophy of the RES. But this ACTH-induced hypertrophy did not lead to the increased tolerance to stress associated ${ }^{27}$ with other techniques of protection. Next it was determined that adrenalectomized rats, maintained on salt or on hydrocortisone, could be gingerly trained to a state of resistance greater than their untrained counterparts, although the magnitude of this resistance was much lower than that produced in intact animals. However, in contrast with the intact trained animal which remains resistant for several weeks the adrenalectomized trained rat spontaneously lost its resistance in 1-2 days. It was interesting that the hydrocortisonetreated rat, while it fared significantly better than the salt-maintained animal, still fell far short of the intact animal in terms of its tolerance to stress. There appears to be, therefore, an as yet undisclosed but real relationship between adrenal secretions, the RES and the circulation.

Admittedly, a rather indirect and poorly marked path has been travelled to this point which is clearly not the end of the road but rather a point of challenge to continue. The challenge is to our viewpoint concerning the site, or to use Henderson's old term, the fulcrum on which the disruption in circulatory homeostasis in shock turns. In the RES there seemingly exists a battery of biologically versatile mechanisms which continuously monitor and regulate the make-up of the blood and which also condition the functioning of vascular and perhaps all endothelial cells. When the RES is challenged it responds by accelerating and adapting its normal functional potential to sustain endothelial integraty by successfully coping with physiologically useless or harmful materials it has ingested. When RES mechanisms are overwhelmed by these deleterious materials, or when it is impaired for any other reason-systemic disease, $\mathrm{X}$-radiation, métabolic disturbances-it cannot meet this challenge, it cannot be stimulated anew to do so. Its functions are transferred, in default, to other endothelial cells, less specialized and less competent to cope with the challenge. These less specialized cells do not possess all the biochemical mechanisms of the RES to deal efficiently with complex proteins, bacterial products and the host of materials released by the generalized tissue hypoxia resulting from the inadequate tissue blood flow in shock. As a result serious damage to endothelial function occurs and provokes the widespread dysfunction of the microcirculation and breakdown of circulatory homeostasis which constitutes the so-called vicious cycle in shock. But the fact that it seems possible to stimulate the RES beyond its normal capacity so that it is less easily overwhelmed or depressed and that such striking resistance to many forms of experimental shock can be induced, imparts a note of optimism to this new look at shock. Finally it should be re-emphasized that this new look proposes to be but a tenuous view and not a completely validated appraisal of a complex and elusive, entity. 


\section{RÉsUMÉ}

L'état actuel de nos connaissances incomplètes sur la pathogénie du choc devient probablement la principale raison de l'usage clinique si limité qu'il a été fait des données expérimentales très étendues et bien à point de cette entité. $D_{e}$ toute évidence, il s'imposẻ de faire une nouvelle mise en valeur de l'amoncellement de données de laboratoire, sous un angle nouveau et différent, pour qu'elles puissent apporter des réponses, longtemps cherchées, à l'étiologie de base du syndrome choc.

La plupart des chercheurs sont d'accord pour affirmer que, essentiellement, le choc est un syndrome de collapsus vasculaires périphériques. Toutefois, il existe encore beaucoup d'incertitude à savoir si ce collapsus micro-circulatoire découle d'abord de plusieurs circonstances et de produits toxiques qui peuvent plus tard aboutir au choc, ou si ce déséquilibre vasculaire est d'abord la conséquence d'une perturbation plus profonde des mécanismes de défense de l'homéostase de l'organisme normal. Il n'xiste pas de théorie ou de conception du choc qui désigne une substance spécifique ou une situation pathologique qui puisse expliquer toutes les manifestations critiques du syndrome. Toutefois, l'accord générale semble se faire et bien des faits le prouvent, sur le fait que l'existence au préalable d'une perturbation (spontanée ou provoquée) des mécanismes naturels de défense rend un animal plus susceptible de faire du choc. Au sujet de l'importance de ces mécanismes de défense, il est également très intéressant de signaler qu'un traitement pré-choc d'un animal, par n'importe quéls moyens qui augmentent le niveau d'activité de ses mécanismes de défense, rend cet animal résistant aux stimuli choquants qui, en temps ordinaire, seraient facilement mortels.

Les processus biologiques par lesquels l'organisme s'adapte ordinairement aux circonstances défavorables de l'ambiance s'appellent: les mécanismes d'adaptation. Il semble logique, en conséquence, d'analyser ou d'examiner d'abord ces mécanismes d'adaptation pour dépister le rôle qu'ils peuvent jouer dans les événements qui conduisent au choc. C'est un fait connu que, dans un groupe d'hommes ou d'animaux, il existe entre les individus une grande marge de tolérance au stress. Le fait de pouvoir délibérément influencer les facteurs qui déterminent la qualité de réponse au stress, réponse dans un sens favorable ou non favorable, donne de précieux renseignements théoriques et pratiques. Depuis des siècles, cela se pratique chez les humains: voir l'entraînement des soldats et des athlètes. Dans les laboratoires, depuis un certain temps, on emploie sur une haute échelle et de façon certaine, une variété de techniques soit pour prédisposer les animaux au stress, soit pour les protéger contre les stimuli stressants. En examinant attentivement les caractéristiques de ces techniques, particulièrement celles qui exercent un effet protecteur, il est possible d'accumuler des renseignements précieux pour comprendre les mécanismes de défense qu'elles influencent.

Cette analyse révèle plusieurs points intéressants. Le premier point est la tolérance croisée à différents types de choc (hémorragique, traumatique, toxique) qu'il est possible d'acquérir par des techniques individuelles de protection. Un autre point consiste en ce que les activités biologiques survenant dans l'intestin et dans le foie jouent un rôle critique dans les défenses de l'organisme contre le 
stress. Enfin, un point d'intérêt spécial réside dans l'observation quee le caractère de l'état de résistance semble étroitement lié au sort de diverses substances tissulaires (histamine̊s, catéchols, sérotonine, polypeptides vasotropiques) substances présentes normalement dans les tissus.

Si l'on peut considérer le choc comme un syndrome de collapsus vasculaire périphérique, il est également une manifestation d'une fonction tissulaire perturbée qui découle d'un collapsus microcirculatoire. La particularité du syndromechoc réside dans le fait que le collapsus vasculaire périphérique et la perturbation tissulaire concomitante deviennent un cercle automatique lequel, à l'oecasion, il devient impossible d'arrèter ou de renverser par n'importe quelle thérapeutique connue. En d'autres termes, la lésion de base semble consister dans le développement d'un complexe vasculaire autonome dans les tissus, complexe dissocié, différent du modèle primitif biologique. Il a été préconisé par Fine et ses associés que le choc irréversible n'était rien d'autre que le résultat de l'effondrement des mécanismes normaux de défense antibactérienne de l'organisme. En principe, sans tenir compte du rôle que Fine fait jouer aux endotoxines bactériennes dans la pathogénie du choc, cet. énoncé a un intérêt spécial. En effet, les défenses anti-bactériennes de l'organisme font partie de l'ensemble des mécanismes de défense de l'organisme et, sans aucun doute, une entité phylogénétiquement primitive. L'analyse des mécanismes antibactériens pourrait donc fournir le secret des défenses que l'organisme met en œuvre pour s'adapter et pour survivre aux situations stressantes comme le choc.

Un grand nombre des défenses contre les bactéries et les produits bactériens sont situés dans le système réticulo-endothélial (R.E.S.). Il est également précieux d'observer que le système réticulo-endothélial phylogénétiquement primitif participe à płusieurs changements physiologiques, on l'a démontré, chez les animaux que l'on protège expérimentalement contre le choc. Encore bien plus, l'on a démontré que le système réticulo-endothélial était un chaînon important dans la série des événements mis en jeu par chaque facteur ou chaque circonstance susceptible de jouer un rôle dans la pathogenèse du choc: la ferritine, les endotoxines, l'hypersensibilité, les thromboses microscopiques, la perméabilité capillaire, etc. Il est établi clairement que le système réticulo-endothélial fonctionne ordinairement de façon continuelle pour phagocyter et paralvser les produits anormaux et toxiques du sang. De cette façon et de bien d'autres, le système réticulo-endothélial voit donc au maintien d'un équilibre normal entre les tissus et la microcirculation. Ses abondantes cellules sont distribuées de façon stratégique, et elles répondent par une hypertrophie anatomique et fonctionnelle à l'apparition dans le sang de quantités anormales de débris cellulaires et de produits toxiques. Tout récemment, l'on a démontré que ce système était également impliqué dans plusieurs autres fonctions homéostatiques importanes, telles que la régulation des plaquettes sanguines, des leucocytes, du volume sanguin, du débit sanguin régional, des anticorps, de l'activité protéolytique, etc.

Expérimentalement, l'on peut mesurer la capacité fonctionnelle du système réticulo-endothéliale en mesurant la vitesse à laquelle sont retirées du courant sanguin les particules colloides inertes injectées, comme par exemple, le carbone, la proferrine ou le radiochrome. De la même façon, pour faire une étude, on peut 
déprimer le système réticulo-endothélial en faisant une seule injection de fortes doses de ces colloides. Ou bien, on peut stimuler ce système en faisant des injections répétées de petites doses de ces substances pendant plusieurs jours. En employant ces façons de procéder, l'on a trouvé que la dépression du système réticulo-endothélial augmentait la sensibilité de l'animal à toutes les sortes de choc. Par contre, une stimulation du système réticulo-endothélial entraînait une protection contre le choc. Encore bien plus, les animaux rendus résistants au choc par d'autres moyens manifesteraient aussi une activité fonctionnelle accrue du système réticulo-endothélial. Dans cette dernière catégorie d'animaux résistants, l'on pouvait inhiber temporairement cet état de résistance en bloquant le système réticulo-endothélial par des doses dépressives de colloides. Il appert donc, d'après ces résultats, que l'activité fonctionnelle du système réticulo-endothélial, lequel inclut une grande partie de l'ensemble des mécanismes de défense normale de l'organisme est un point critique déterminant l'ensemble des caractèrề de la réponse aux stimuli choquants.

Cette analyse de l'existence de renseignẻments expérimentaux concernant le syndrome-choc sous cet aspect ne devient rien d'autre que le début de la route qu'il faudrait continuer à explorer. Elle attire l'attention sur un mécanisme: le système réticulo-endothélial, qui est phylogénétiquement primitif, souple et en étroite relation avec tout autre facteur éventuel que l'on soupçonne de prendre part ou qui, de fait, tel que démontré, prend part à la lutte mortelle du syndrome. choc. La bibliographie documentant sur la relation du système réticulo-endothélial et du choc est encore bien incomplète, mais de plus amples études de ce système semblent des plus prometteuses poưr nous aider à resoudre le problème du choc.

\section{REFERENCES}

1. Jacob, S., Weizel, H., Gordon, E., Korman, H., Schweindurg, F. B, Frank, H. A, \& FINE, J. Bactenal Action in Development of Irreversibility to Transfusion in Hemorrhagic Shock in Dog. Am. J. Physiol. 179: 523 (1954).

2. Noble, R. Development of Resistance by Rats and Guinea Pigs to Amounts of Trauma Usually Fatal. Am. J. Physiol. 138: 346 (1943).

3. Hershey, S. G., Zweifach, B. W., \& Antopol, W. Factors associated with protection against Experimental Shock. Anesthesiology 17: 265 (1956).

4. SmIDDy, F. G., SEgaI D., FINE, J. Host Resistance to Hemorrhagic Shock; Mechanism of Protective Action of Dibenamine. Proc. Soc. Exper. Biol. \& Med. 97: 584 (1958).

5. Selye, H. The General Adaptation Syndrome and the Diseases of Adaptation. J. Clin Endocrimol. 6: 117 (1946). a

6. Hershey, S. G., Baez, S., \& Rovenstine, E. A. Intestinal Ischemia|(SMA) Shock| in Normal and Dibenzyline Protected Dogs. Am. J. Physiol. (in press).

7. Rovenstine, E. A.; Hershey, S. G.; Lanza, S., Baez, A.; \& Baez, S. Relationship of Bowel and liver to Drug Protection against Shock. Anesthesiology 20:290 (1959)

8. Zweifach, B. W., Metz, D. B., \& Shorr, E. Participation of VEM and VDM Mechanisms in Drum Shock and in Development of "Resistance" to Drum Trauma. Am. J. Physiol 164: 91 (1951).

9. Shorr, E., Mazur, A., \& Baez, S. Chemical and Biological Properties of the hepatorenal Factors VEM and VDM (ferritin). Recent Progress in Hormone Research II 453; New York: Academic Press (1955).

10. Baez, S., Hershey, S. G., \& Rovenstine, E. A. Vasotropic Substances in the Blood in Intestinal Ischemia (SMA) Shock. Am. J. Physiol. (in press).

11. ZWEIFACH, B. W. Microcirculatory Derangements as Basis for Lethal Manifestations of Experimental Shock. Brit. J. Anaesth! 30: 466 ( I958). 
12. Hershey, S. G. Current Theories of Shock. Anesthesiology 21:303 (1960).

13. Hershey, S. G. Experimental protection against shock, Wisconsin Med. J. 58: 643 (1959).

14. LilleIHEI, R. C. Intestinal Factor in Irreversible Hemorrhage Shock. Surgery 42: 1043 (1957).

15. Selkurt, E. E. Mesenteric hemodynamics during hemorrhagic shock in dog with functional absence of liver. Am. J. Physiol. 193: 599 (1958).

16. Shorr, E.; ZweIFACH, B. W.; Furchgotr, R. F.; \& BAEz, S. Hepatorenal Factors in Circulatory Homeostasis; Tissue Origins of Vasotropic Principles VEM and VDM, Which Appear during Evolution of Hemorrhagic and Tourniquet Shock. Circulation 3: 42 (1951).

17. Fine, J. Host Resistance to Bacterial Infection in Traumatic Shock. Brit. J. Anaesth. 30: 485 (1958).

18. Green, S., Mazur, A., \& Shorr, E. Mechanism of Catalytic Oxidation of Adrenaline by Ferritin. J. Biol. Chem. 213: 147 (1955):

19. Thomas, L., Zweifach, B. W., \& Benacerraf, B. Mechanisins in Production of Tissue Damage and Shock by Endotoxin. Tr. A. Am. Physicians 70: 54 (1957).

20. Fine, J. The Bacterial Factor in Traumatic Shock. Springfield, Ill.: Chas. C. Thomas (1954).

21. HaLPern, B. N. (Editor). Pathophysiology of the Reticulo-endothelial System. Symposium sponsored by Council for International Organizations for Medical Sciences; Springfield, Ill.: Chas. C. Thomas (1957).

22. Various Authons. Conference on Recticulo-Endothelial System (Dec. 1959). New York Ac. Sci., Ann. New York Ac. Sci. (in press).

23. Biozzi, G. B., Benacerraf, B., \& Halpern, B. N. A study of the kinetics of granulopectic activity of the RES in relation to the dose of carbon injected. Brit. J. Exper. Pathol. 34: 441 (1953).

24. McKenna, J. M., \& Zweifach, B. W. Reticulo-Endothelial System in relation to Drum Shock. Am. J. Physiol. 187: 263 (1956).

25. Fine, J., Rutenburg, S. H., \& Schwéinburg, F. B. Role of the Reticulo-Endothelial System in Shock. J. Exper. Med. 110: 547 (1959).

26. Zweifach; B. W., \& BenacerraF, B. Effect of Hemorrhagic Shock on the Phagocytic Function of Kupffer Cells. Circ. Research 6: 83 (1958).

27. ZweIFach, B. W. The Contribution of the Reticulo-Endothelial System to the Development of Tolerance to Experimental Shock. Ann. New York Ac. Sci. 88: 203 (1960).

\section{ERRATUM}

The acknowledgment of the paper entitled "Central Effects, of Five Muscle Relaxants" by L. W. Hersey, C. W. Gowdey and W. E. Spoerel, which appeared in the Canadian Anaesthetists' Society Journal, Volume 8 (July 1961) on page 344 should read as follows: "This study was supported in.part by a grant from Burroughs Wellcome and Company, Montreal, Canada and in part by the J. P. Bickell Foundation. We wish to thank Dr. J. R. Bogert, Medical Director of Burroughs Wellcome for his interest in this problem." 